\title{
Dietary level of cull pinto beans on nutrient digestibility and animal performance of finishing hair lambs
}

\author{
Francisco Castillo Rangel ${ }^{1}$, Guillermo Villalobos Villalobos ${ }^{1 *}$, David Domínguez Díaz ${ }^{1}$, Juan \\ Ángel Ortega Gutiérrez ${ }^{1}$
}

\footnotetext{
${ }^{1}$ Universidad Autónoma de Chihuahua, Facultad de Zootecnia y Ecología, Chihuahua, Chihuahua, México.
}

\begin{abstract}
The objective was to evaluate the effect of cull pinto beans (CPB) (Phaseolus vulgaris) on performance of feedlot lambs. Seventy-two crossbred hair-breed lambs (Dorper $\times$ Pelibuey and Kathadin $\times$ Pelibuey) were used $(75 \pm 6$ days old and $18.7 \pm 3.89 \mathrm{~kg}$ of initial body weight). Animals were fed twice daily. Diets consisted of $20 \%$ alfalfa hay and $80 \%$ concentrate based on ground sorghum grain and were formulated to contain $17.9 \%$ crude protein and $2.60 \mathrm{Mcal} / \mathrm{kg}$ metabolizable energy. Treatments were (dry matter basis): no CPB (0\%), 10\% CPB, and 20\% CPB. Lambs were blocked by body weight and treatments and arranged in a $2 \times 3$ arrangement of treatments. Body weights were recorded initially and subsequently at 14-day intervals for a total 70 number of days. Dry matter intake was recorded daily. Apparent dry matter digestibility was predicted using insoluble acid detergent fiber. Data were analyzed as a randomized complete block design. Final body weight and average daily gain decreased linearly with increasing CPB level and were greater for males than females. A level $\times$ gender interaction was observed for dry matter and crude protein digestibility. Data for hot carcass weight and cold carcass weight decreased linearly as CPB level increased and were greater for males. Carcass yield, longissimus muscle area, and dressing percentage were greater for males. Dressing percentage quadratically increased as CPB level increased. Cull pinto beans are a suitable ingredient for feedlot hair-breed lambs, but the inclusion of more than $10 \%$ of $\mathrm{CPB}$ level decreases animal performance.
\end{abstract}

Key Words: legumes, ovines, Phaseolus vulgaris

\section{Introduction}

Feed price increments have driven sheep producers to look for new alternatives in animal feeding. Agricultural byproducts are alternatives to replace high-priced grains. An alternative is cull pinto beans (CPB, Phaseolus vulgaris L.) popularly known as kidney beans. Mexico has an inventory of 7,306,600 sheep (INEGI, 2007), of which the main product is finished lambs for the domestic market. Feeding lambs in feedlot is a common practice in Mexico. Also, about 1.7 million ha are planted with beans (SIAP, 2010). In 2014, 1,273,957.14 tons of beans were produced in Mexico (SIAP, 2016). Therefore, those that do not fulfill the quality standards for human consumption $(20 \%$

Received: May 3, 2016

Accepted: November 6, 2016

*Corresponding author: gvilla@uach.mx

http://dx.doi.org/10.1590/S1806-92902017000500005

How to cite: Castillo Rangel, F.; Villalobos Villalobos, G.; Domínguez Díaz, D. and Ortega Gutiérrez, J. A. 2017. Dietary level of cull pinto beans on nutrient digestibility and animal performance of finishing hair lambs. Revista Brasileira de Zootecnia 46(5):400-404

Copyright (c) 2017 Sociedade Brasileira de Zootecnia. This is an Open Access article distributed under the terms of the Creative Commons Attribution License (http://creativecommons.org/licenses/by/4.0/), which permits unrestricted use, distribution, and reproduction in any medium, provided the original work is properly cited. approximately) can be potentially used in animal feeding. So, CPB represent a good source of protein, vitamins and minerals, and complex carbohydrates. However, they also contain anti nutritional factors such as protease inhibitors and polyphenols, lectins, and phytic acid, among others (Mejía et al., 2003), causing a detrimental effect on diet quality (Díaz-Batalla et al., 2006). Nonetheless, their effect on finishing hair-breed lambs fed high-concentrate diets is unknown and feeding high-concentrate diets is not a common practice in Mexico (Villalobos et al., 2006). It was hypothesized that the use of CPB would be a good feed alternative for hair-breed lambs. Therefore, the objective of this study was to evaluate the effect of three levels of CPB supplement on animal performance, apparent digestibility, and carcass characteristics of finishing hair-breed lambs.

\section{Material and Methods}

All procedures involving animals were approved by local official techniques for animal care (NOM-051-ZOO1995: Humanitarian care of animals during mobilization of animals and NOM-024-ZOO-1995: Animal health stipulations and characteristics during transportation of animals). This study was conducted in Chihuahua city, Chihuahua, México (28 35'09"N and 106 06'27"W). 
Seventy-two crossbred hair-breed lambs (Dorper $x$ Pelibuey and Katahdin $\times$ Pelibuey) were used (36 ewe lambs and 36 wethers, $75 \pm 6$ days of age and $18.7 \pm 3.89 \mathrm{~kg}$ of initial body weight). At the start of the experiment, all lambs were identified, vaccinated with a three-way clostridial vaccine (Bacterina triple bovina, Bio - ZOO S.A. de C.V., Zapopan, Jalisco, Mexico), treated for external and internal parasites with ivermectin (Iverfull, Aranda Salud Animal, Querétaro, Querétaro, México), and received vitamin A, $\mathrm{D}$, and $\mathrm{E}$ supplement. Lambs were sorted by gender and assigned within gender to one of four body weight (BW) blocks. Within each gender/BW block, three animals were assigned at random to a pen (outdoors; $2.5 \times 2 \mathrm{~m}$ ), thus forming three gender/BW pens. Then, the three pens within each gender/BW block were allocated at random to one of the three dietary treatments. Therefore, there were a total of 24 pens, each containing three lambs and the experimental design was a randomized block with a factorial arrangement of two genders (wether, ewe) $\times 3$ levels of CPB $(0 \%, 10 \%$, $20 \%) \times 4$ replicates (blocks) with pens of three lambs forming the experimental plots. Diets were mixed weekly and consisted of $20 \%$ alfalfa hay and $80 \%$ concentrate based on ground sorghum grain. Treatments consisted (dry matter basis) of: $0 \% \mathrm{CPB}$, control; $10 \% \mathrm{CPB}$ (low cull pinto beans); and 20\% CPB (high cull pinto beans) in the total diet, with beans replacing ground sorghum grain, cottonseed meal, and corn distillers' grains in the ration. Diets were formulated to contain $17.9 \%$ of crude protein and $2.60 \mathrm{Mcal} / \mathrm{kg}$ of metabolizable energy (Table 1). The diets were offered ad libitum with the food being refreshed

Table 1 - Diet composition ( $\mathrm{g} \mathrm{kg}^{-1}$ of dry matter) for finishing hair lambs fed cull pinto beans (Phaseolus vulgaris L.)

\begin{tabular}{lccc}
\hline & \multicolumn{3}{c}{ Proportions of cull pinto beans ${ }^{1}$} \\
\cline { 2 - 4 } Item & Control & LCPB & HCPB \\
\hline Ingredient composition $\left(\mathrm{g} \mathrm{kg}^{-1}\right.$ of DM) & & \\
Alfalfa hay & 202.6 & 201.1 & 200.8 \\
Ground sorghum grains & 474.5 & 473.3 & 422.5 \\
Cull pinto beans & - & 99.9 & 199.9 \\
Cottonseed meal & 188.8 & 118.5 & 114.8 \\
Corn distillers grains & 101.3 & 76.6 & 31.3 \\
Animal fat & 20.9 & 19.1 & 19.1 \\
Mineral Premix & 05.1 & 05.0 & 05.0 \\
Sodium chloride & 05.1 & 05.0 & 05.0 \\
Calcium carbonate & 01.7 & 01.5 & 01.6 \\
Calculated chemical composition $\left(\mathrm{g} \mathrm{kg}{ }^{-1}\right.$ & of DM) & & \\
Crude protein & 179.0 & 179.0 & 179.0 \\
Metabolizable energy (Mcal $/ \mathrm{kg})$ & 2.60 & 2.60 & 2.60 \\
Neutral detergent fiber & 148.9 & 137.5 & 117.9 \\
Lignin & 25.3 & 23.7 & 21.7 \\
Ca & 05.7 & 05.4 & 05.4 \\
P & 05.1 & 04.2 & 03.8 \\
\hline
\end{tabular}

DM - dry matter.

${ }^{1}$ Control - $0 \%$ cull pinto beans; LCPB - low cull pinto beans ( $10 \%$ cull pinto beans); HCPB - high cull pinto beans ( $20 \%$ cull pinto beans) (dry matter basis). at 7.00 and $17.00 \mathrm{~h}$ daily; lambs were allowed free access to water. During the experiment, two lambs from low CPB and one lamb from control group were removed from the study because of respiratory disease that was not related to the treatments. Animals were gradually adjusted to an $80 \%$ concentrate diet before the trial started.

Body weights were recorded initially and subsequently at 14-day intervals for a total of 70 days. Feed and refusal (10\%) samples were taken once weekly and composite samples were formed over 14-day intervals.

Feed samples were ground in a Wiley mill through a 1-mm screen (Wiley mill model 4, Thomas Scientific, Swedesboro, NJ) and subjected to all or part of the following analysis: dry matter, organic matter, and crude protein, methods $930.15,942.15$, and 990.02, respectively (AOAC, 1997). Acid detergent fiber and neutral detergent fiber were determined sequentially according to Van Soest et al. (1991) using an Ankom 200 fiber analyzer (Ankom Technology, Fairport, NY).

One animal from each of the 24 pens (the one that represent the average body weight for the pen) was selected to evaluate experimental diet digestibility $(34 \pm 4.1 \mathrm{~kg}$ of body weight and $163 \pm 6$ days of age). Animals were kept outdoors in pens $(2.5 \times 2 \mathrm{~m})$ and the same schedule of feeding regime was followed. The digestibility trial was eight days in length, with five days for dry matter intake (DMI) measurements, and three days for fecal collections. During collection, fecal samples were taken directly from the rectum four times daily as follows: day 1, 08.00, 10.00, 12.00 , and $14.00 \mathrm{~h}$; day $2,16.00,18.00,20.00$, and $22.00 \mathrm{~h}$; and day 3,00.00, 02.00, 04.00, and $06.00 \mathrm{~h}$. Individual fecal samples consisted of approximately $50 \mathrm{~g}$ (wet basis). Samples for each animal were composited for analysis and stored at $-20{ }^{\circ} \mathrm{C}$.

Composited fecal samples were dried in a forced-air oven $\left(60^{\circ} \mathrm{C}\right)$ for five days. Feed, orts, and fecal samples were ground in a Wiley mill through a 1-mm screen and analyzed for dry matter, organic matter, crude protein, acid detergent fiber, and neutral detergent fiber as described previously. Feed and fecal samples were incubated in a DAISY ${ }^{\mathrm{II}}$ system (Ankom Technology Corp. Fairport, NY) during five days (Mabjeesh et al., 2000). After incubation, bags were washed four times with cold water for $5 \mathrm{~min}$ and then dried $\left(60^{\circ} \mathrm{C}\right)$ for $24 \mathrm{~h}$. Concentration of acid detergent fiber was determined in the bag residue to calculate the percentage of indigestible acid detergent fiber (iADF) (Penning and Johnson, 1983).

Apparent dry matter digestibility was predicted using insoluble acid detergent fiber according to the following formula (Schneider and Flatt, 1975): 


$$
\mathrm{DMD}=100-\left[100 \times\left(\frac{\% \text { IADF in feed }}{\% \text { IADF in feces }}\right)\right]
$$

Apparent digestibility of crude protein and neutral detergent fiber were calculated using the formula:

Nutrient digestibility (ND) $=100-\left[100 \times\left(\frac{\% \text { IADF in feed }}{\% \text { IADF in feces }} \times \frac{\% \text { of nutrient in feces }}{\% \text { of nutrient in feed }}\right)\right]$

Lambs were slaughtered after concluding the digestibility trial. Food was withheld for $18 \mathrm{~h}$ and water for $12 \mathrm{~h}$ before slaughter and their fasted body weight was taken just before slaughter. Hot carcass weight (HCW) was determined on the day of slaughter. Carcass yield was calculated with the formula $\mathrm{CY}=(\mathrm{HCW} \times 100) /$ slaughter weight. Carcasses were chilled for $36 \mathrm{~h}$ at $4{ }^{\circ} \mathrm{C}$ and cold carcass weight (CCW) was recorded. Carcasses were ribbed at the 12th rib, and longissimus muscle area was measured between the 12th and 13th ribs (USDA, 1992). Dressing percentage was estimated as $(\mathrm{CCW} \times 100) /$ slaughter weight.

Data were analyzed as a completely randomized block design using the MIXED procedure of SAS (Statistical Analysis System, version 9.1.3). Pen was the experimental unit. When significant $(\mathrm{P}<0.05), \mathrm{F}$-statistics were obtained and means were separated using polynomial contrast.

The mathematical model used was:

$$
\mathrm{y}_{\mathrm{ijk} k \mathrm{~m}}=\mu+\tau_{\mathrm{i}}+\rho_{\mathrm{j}}+\sigma_{\mathrm{k}}+\Theta_{\mathrm{ik}}+\mathrm{a}_{\mathrm{l}}+\mathrm{b}_{\mathrm{m}}+\mathrm{e}_{\mathrm{ijk} k \mathrm{~m}},
$$

in which $\mathrm{y}_{\mathrm{ijklm}}=$ observed value of the variable that received the level of CPB i, day j, gender k, block 1, and pen m; $\mu=$ overall mean; $\tau_{\mathrm{i}}=$ dietary level of CPB effect; $\rho_{\mathrm{j}}=$ effect of the day of measurement; $\sigma_{\mathrm{k}}=$ effect of gender; $\Theta_{\mathrm{ik}}=$ interaction between level of CPB and effect of gender; $\mathrm{a}_{1}=\mathrm{BW}$ block; $\mathrm{b}_{\mathrm{m}}=$ effect of pen; and $\mathrm{e}_{\mathrm{ijklm}}=$ random error associated with each observation.

\section{Results}

Initial body weight $(\mathrm{kg})$ was not different among treatments $(\mathrm{P}>0.05)$. Final body weight and average daily gain (ADG) decreased linearly $(\mathrm{P}<0.01)$ with increasing CPB level (Table 2) and was greater $(\mathrm{P}<0.01)$ for males. Dry matter intake was not affected $(\mathrm{P}>0.05)$ by $\mathrm{CPB}$ level; however, it was greater for males than for females $(\mathrm{P}<0.04)$. As a result of the linear decrease in average daily gain without

Table 2 - Effect of levels of cull pinto beans on animal performance, apparent digestibility, and carcass composition of finishing hair

\begin{tabular}{|c|c|c|c|c|c|c|c|c|c|c|c|c|}
\hline \multirow[t]{2}{*}{ Item } & \multicolumn{3}{|c|}{$\begin{array}{l}\text { Proportions of cull } \\
\text { pinto beans }{ }^{1}\end{array}$} & \multirow[t]{2}{*}{ SEM } & \multicolumn{2}{|c|}{ Gender } & \multirow[t]{2}{*}{ SEM } & \multicolumn{3}{|c|}{ P-value ${ }^{2}$} & \multicolumn{2}{|c|}{ Contrast $^{3}$} \\
\hline & Control & $\mathrm{LCPB}$ & HCPB & & Male & Female & & TRT & Gender & TRT $\times$ Gender & $\mathrm{L}$ & Q \\
\hline Initial body weight (kg) & 18.40 & 17.70 & 18.10 & 1.93 & 18.60 & 17.50 & 1.91 & 0.60 & 0.09 & 0.52 & 0.69 & 0.36 \\
\hline Final body weight (kg) & 36.20 & 32.90 & 32.20 & 2.13 & 36.50 & 31.00 & 2.09 & $<0.01$ & $<0.01$ & 0.09 & $<0.01$ & 0.13 \\
\hline $\mathrm{ADG}(\mathrm{kg})$ & 0.25 & 0.22 & 0.20 & 0.01 & 0.26 & 0.19 & 0.01 & $<0.01$ & $<0.01$ & 0.14 & $<0.01$ & 0.25 \\
\hline DMI (kg/d) & 1.17 & 1.13 & 1.12 & 0.07 & 1.21 & 1.07 & 0.06 & 0.79 & 0.04 & 0.94 & 0.55 & 0.76 \\
\hline DMI:ADG & 4.70 & 5.20 & 5.50 & 0.32 & 4.70 & 5.50 & 0.27 & 0.15 & 0.03 & 0.81 & 0.06 & 0.89 \\
\hline $\begin{array}{l}\text { Apparent digestibility } \\
\text { of DM }\left(\mathrm{g} \mathrm{kg}^{-1}\right)\end{array}$ & 718.00 & 712.00 & 708.00 & 07.20 & 712.00 & 713.00 & 6.00 & 4.30 & 9.20 & 0.30 & 2.10 & 8.70 \\
\hline Male & 731.00 & 701.00 & 705.00 & 08.30 & - & - & - & 0.60 & - & - & 0.50 & 1.20 \\
\hline Female & 705.00 & 723.00 & 710.00 & 09.90 & - & - & - & 2.00 & - & - & 6.00 & 0.90 \\
\hline $\begin{array}{l}\text { Apparent digestibility } \\
\text { of NDF }\left(\mathrm{g} \mathrm{kg}^{-1}\right)\end{array}$ & 242.00 & 231.00 & 243.00 & 29.10 & 259.00 & 219.00 & 23.70 & 9.50 & 2.50 & 9.60 & 9.70 & 7.40 \\
\hline $\begin{array}{l}\text { Apparent digestibility } \\
\text { of } \mathrm{CP}\left(\mathrm{g} \mathrm{kg}^{-1}\right)\end{array}$ & 656.00 & 633.00 & 620.00 & 19.00 & 649.00 & 631.00 & 17.00 & 1.00 & 2.90 & 0.40 & 0.40 & 5.90 \\
\hline Male & 707.00 & 616.00 & 624.00 & 24.50 & - & - & - & 0.60 & - & - & 0.40 & 1.30 \\
\hline Female & 625.00 & 650.00 & 617.00 & 23.70 & - & - & - & 5.30 & - & - & 7.90 & 2.90 \\
\hline Digestible DMI (kg) & 0.88 & 0.87 & 0.77 & 0.04 & 0.92 & 0.76 & 0.03 & 0.11 & $<0.01$ & 0.05 & 0.06 & 0.38 \\
\hline Male & 0.90 & 1.03 & 0.84 & 0.07 & - & - & - & 0.11 & - & - & 0.44 & 0.05 \\
\hline Female & 0.86 & 0.71 & 0.71 & 0.03 & - & - & - & 0.03 & - & - & 0.02 & 0.15 \\
\hline Digestible NDFI (kg) & 0.05 & 0.05 & 0.05 & 0.01 & 0.06 & 0.04 & 0.01 & 0.74 & 0.03 & 0.93 & 0.45 & 1.00 \\
\hline Digestible CP (kg) & 0.14 & 0.13 & 0.11 & 0.01 & 0.14 & 0.11 & 0.01 & 0.04 & $<0.01$ & 0.50 & 0.01 & 1.00 \\
\hline Slaughter body weight (kg) & 35.20 & 34.30 & 32.80 & 1.43 & 36.70 & 31.50 & 1.36 & 0.10 & $<0.01$ & 0.40 & 0.04 & 0.79 \\
\hline Hot carcass weight $(\mathrm{kg})$ & 17.30 & 17.10 & 16.10 & 0.97 & 17.80 & 15.90 & 0.95 & 0.07 & $<0.01$ & 0.58 & 0.03 & 0.39 \\
\hline Cold carcass weight (kg) & 17.00 & 16.80 & 15.50 & 0.96 & 17.20 & 15.60 & 0.93 & 0.04 & $<0.01$ & 0.47 & 0.02 & 0.24 \\
\hline Carcass yield & 49.30 & 49.80 & 48.90 & 0.97 & 50.40 & 48.30 & 0.92 & 0.50 & $<0.01$ & 0.91 & 0.64 & 0.28 \\
\hline $\operatorname{LMA}\left(\mathrm{cm}^{2}\right)$ & 22.80 & 22.00 & 23.00 & 1.18 & 24.90 & 20.30 & 1.06 & 0.72 & $<0.01$ & 0.35 & 0.85 & 0.43 \\
\hline Dressing percentage & 48.30 & 49.00 & 47.30 & 0.92 & 46.80 & 49.60 & 0.88 & 0.05 & $<0.01$ & 0.41 & 0.15 & 0.04 \\
\hline
\end{tabular}
lambs

ADG - average daily gain; DMI - dry matter intake; DM - dry matter; NDF - neutral detergent fiber; CP - crude protein; NDFI - neutral detergent fiber intake; LMA - longissimus muscle area; SEM - standard error of the mean.

${ }^{1}$ Control - $0 \%$ cull pinto beans; LCPB - low cull pinto beans ( $10 \%$ cull pinto beans); HCPB - high cull pinto beans (20\% cull pinto beans) (dry matter basis).

${ }^{2}$ Probabilities for the treatment (TRT), lamb gender (Gender), and interaction of treatment $\times$ lamb gender (TRT $\times$ Gender) effect.

${ }^{3}$ Probabilities for the linear (L) and quadratic (Q) effects of cull pinto bean levels. 
effect on dry matter intake with increasing CPB level, DMI:ADG ratio $(\mathrm{P}>0.05)$ increased linearly as $\mathrm{CPB}$ level increased and it was greater $(\mathrm{P}<0.03)$ for females than for males.

Cull pinto beans level $\times$ gender interaction $(\mathrm{P}<0.03)$ was observed for apparent dry matter digestibility. Dry matter digestibility for males linearly decreased $(\mathrm{P}<0.05)$ but quadratically increased for females $(\mathrm{P}>0.05)$ with increasing CPB level (Table 2). Apparent digestibility of neutral detergent fiber was not affected $(\mathrm{P}>0.05)$ by $\mathrm{CPB}$. Cull pinto beans level $\times$ gender interaction was observed for apparent digestibility of crude protein $(\mathrm{P}<0.04)$ and it decreased for males $(\mathrm{P}<0.04)$ and was unaffected for females $(\mathrm{P}>0.05)$. Data for digestible dry matter intake showed a $\mathrm{CPB}$ level $\times$ gender interaction $(\mathrm{P}<0.05)$. For males, digestible dry matter intake quadratically increased $(\mathrm{P}<0.05)$, but for females, it linearly decreased $(\mathrm{P}<0.02)$ with increasing level of $\mathrm{CPB}$ in the diet. Digestible neutral detergent fiber intake was greater $(\mathrm{P}<0.03)$ for males than for females, while digestible crude protein intake linearly decreased $(\mathrm{P}<0.01)$ with increasing $\mathrm{CPB}$ level in the diet and it was greater $(\mathrm{P}<0.01)$ for males than females.

Slaughter body weight $(\mathrm{P}<0.04)$, hot carcass weight $(\mathrm{P}<0.03)$, and cold carcass weight $(\mathrm{P}<0.02)$ decreased linearly with increasing $\mathrm{CPB}$ and were greater $(\mathrm{P}<0.01)$ for males. Similarly, carcass yield, longissimus muscle area, and dressing percentage were greater $(\mathrm{P}<0.01)$ for males. In addition, dressing percentage quadratically increased $(\mathrm{P}<0.04)$ with increasing CPB.

\section{Discussion}

Decreased performance could have been from possible effects of anti-nutritional factors on protein digestibility in the small intestine (Mejía et al., 2003). Different studies have shown the negative effects of anti-nutritional factors when high levels of legumes are offered to ruminants. These results are in agreement to those found in the present study. Williams et al. (1984) showed that yearling cattle fed raw kidney beans had greater circulating antibodies to bean lectins, indicating absorption of lectins. Rush et al. (1998), in a study in which steers were fed different levels of cull dry edible beans $(0,7.5$, and $15 \%$ of dry matter) found that, as level of beans increased in the ration, the body weight gains decreased linearly. Similar to the results of Rush et al. (1998), average daily gain was lowest in steers receiving diet containing the greatest proportion of beans (Williams et al., 1984). Moreover, average daily gain decreased linearly with increasing lentil screenings $(0,12.5,25$, and $33 \%$ ) in feedlot lamb diets (Stanford et al., 1999). Feeding growing animals on diets containing beans as a source of protein brings about a number of undesirable effects. These effects are basically reflected by growth inhibition, poor nitrogen balance, and reduced intestinal absorption of sugars and amino acids (Marzo et al., 2002). Williams et al. (1984) concluded that the toxic nature of kidney beans (Phaseolus vulgaris L. cv. Processor) is not restricted to monogastric animals.

Gilbery et al. (2007) found that field peas, cheakpeas, or lentils did not affect dry matter intake in feedlot cattle when corn-based diets were provided and Lardy et al. (2009) found that field peas did not affect dry matter intake of finishing feedlot steers. Dry matter intake has been reported to decrease with the inclusion of beans (Rush et al., 1998), kidney beans (Williams et al., 1984), lentil screenings (Stanford et al., 1999), and field peas (Soto-Navarro et al., 2004) on diets for lambs or cattle. Rush et al. (1998) reported improvements of DMI:ADG ratio when including dry edible beans in diets for growing cattle. Available data agree with our results. The amount of feed required per unit of gain has been reported to increase in diets containing kidney beans (Williams et al., 1984) or lentil screenings (Surra et al., 1992; Stanford et al., 1999). However, faba beans did not affect DMI:ADG ratio in lamb diets (Surra et al., 1992).

Because dry matter intake was not affected by CPB level, the decrease in average daily gain is attributed to the decreased in digestibility of dry matter and crude protein. Researchers have shown that feeding raw beans to young pigs can negatively affect protein digestibility, reduce pancreatic trypsin, chymotrypsin, and amylase activity and reduce systemic protein utilization (Myer et al., 1982; Myer and Froseth, 1983). Enzyme inhibitors can diminish protein digestibility and lectins can reduce nutrient absorption (Lajolo and Genovese, 2002). The presence of these antinutritional factors could explain the decrease in digestibility and, therefore, the decrease in performance. In agreement with present results, Williams et al. (1984) reported that raw beans caused diarrhea and depressed performance in young ruminants fed feedlot diets. Similarly, Stanford et al. (1999) reported that lentil screenings decreased apparent digestibility of dry matter, organic matter, and neutral detergent fiber. Moreover, Soto-Navarro et al. (2004) found that field peas decreased forage crude protein in situ degradation. Including $\mathrm{CPB}$ in the diet affects carcass weight. Addition of this ingredient can be justified when the cost allows its inclusion. Because the reduction in carcass weights, more time on feed is necessary to achieve the cold carcass weight required by the local market for finished lambs. More information is necessary to understand the effects of legume grains on organoleptic characteristics of meat lamb. 


\section{Conclusions}

Cull pinto beans are a suitable substitute up to $10 \%$ for a combination of sorghum grain, cottonseed meal, and corn distillers' grains in a concentrate diet. However, inclusion of cull pinto beans in more than $10 \%$ in concentrate diets for lambs results in negative effects on apparent dry matter and crude protein digestibilities, animal performance, and carcass characteristics.

\section{Acknowledgments}

Appreciation is expressed to Fundación Produce for its financial support.

\section{References}

AOAC - Association of Official Analytical Chemistry. 1997. Official methods of analysis. 16th ed. AOAC International, Gaithersburg, MD.

Díaz-Batalla, L.; Widholm, J. M.; Fahey, G. C.; Castaño-Tostado, J. E. and Paredes-López, O. 2006. Chemical components with health implications in wild and cultivated mexican common bean seeds (Phaseolus vulgaris L.). Journal of Agricultural and Food Chemistry 54:2045-2052.

Gilbery, T. C.; Lardy, G. P.; Soto-Navarro, S. A.; Bauer, M. L. and Anderson, V. L. 2007. Effect of field peas, chickpeas, and lentils on rumen fermentation, digestion, microbial protein synthesis, and feedlot performance in receiving diets for beef cattle. Journal of Animal Science 85:3045-3053.

INEGI - Instituto Nacional de Estadísticas, Geografía e Informática. 2007. Estados Unidos Mexicanos. Censo Agropecuario 2007. VIII Censo Agrícola, Ganadero y Forestal.

Lajolo, F. M. and Genovesse, M. I. 2002. Nutritional significance of lectin and enzyme inhibitors from legumes. Journal of Agricultural and Food Chemistry 50:6592-6598.

Lardy, G. P.; Loken, B. A.; Anderson, V. L.; Larson, D. M.; MaddockCarlin, K. R.; Ilse, B. R.; Maddock, R.; Leupp, J. L.; Clark, R.; Paterson, J. A. and Bauer, M. L. 2009. Effects of increasing field pea (Pisum sativum) level in high-concentrate diets on growth performance and carcass traits in finishing steers and heifers. Journal of Animal Science 87:3335-3341.

Mabjeesh, S. J.; Cohen, M. and Arieli, A. 2000. In vitro methods for measuring the dry matter digestibility of ruminant feedstuffs: Comparison of methods and inoculums source. Journal of Dairy Science 83:2289-2294.

Marzo, F.; Alonso, R.; Urdaneta, E.; Arricibita, F. J. and Ibanez, F. 2002. Nutritional quality of extruded kidney bean (Phaseolus vulgaris $\mathrm{L}$. var. Pinto) and its effects on growth and skeletal muscle nitrogen fractions in rats. Journal of Animal Science 80:875-879.

Mejía, E. G.; Guzmán-Maldonado, S. H.; Acosta Gallegos, J. A.; Reynoso-Camacho, R.; Ramírez-Rodríguez, E.; Pons-Hernández, J. L.; González-Chavira, M. M.; Castellanos, J. Z. and Kelly, J. D. 2003. Effect of cultivar and growing location on the tripsin inhibitors, tannins and lectins of common beans (Phaseolus vulgaris L.) grown in the semiarid highlands of Mexico. Journal of Agricultural and Food Chemistry 51:5962-5966.

Norma Oficial Mexicana NOM-024-ZOO-1995, Especificaciones y características zoosanitarias para el transporte de animales, sus productos y subproductos, productos químicos, farmacéuticos, biológicos y alimenticios para uso en animales o consumo por éstos. Diario Oficial de la Federación, 16 de Octubre de 1995.

Norma Oficial Mexicana NOM-051-ZOO-1995, Norma oficial para trato humanitario en la movilización de animales. Diario Oficial de la Federación, 23 de Marzo de 1998.

Myer, R. O. and Froseth, J. A. 1983. Heat-processed small red beans (Phaseolus vulgaris) in diets for young pigs. Journal of Animal Science 56:1088-1096.

Myer, R. O.; Froseth, J. A. and Coon, C. N. 1982. Protein utilization and toxic effects of raw beans (Phaseolus vulgaris) for young pigs. Journal of Animal Science 55:1087-1098.

Penning, P. D. and Johnson, R. H. 1983. The use of internal markers to estimate herbage intake and digestibility. 1. Indigestible acid detergent fiber. Journal of Agricultural Science 100:133-138.

Rush, I. G.; Weichenthal, B. and Van Pelt, B. 1998. Cull dry edible beans in growing calf rations. University of Nebraska - Lincoln. Nebraska beef cattle reports. Available: <http://digitalcommons. unl.edu/animalscinbcr/356>. Accessed on: June 23, 2015.

Schneider B. H. and Flatt, W. P. 1975. Evaluation of feed trough digestibility experiments. University of Georgia Press, Athens.

SIAP - Servicio de Información Agroalimentaria y Pesquera. 2010 Cierre de la producción agrícola para el año 2009. Available at: $<$ http://www.siap.gob.mx/index.php?option=com wrapper\&view $=$ wrapper\&Itemid $=350>$. Accessed on: July 17, 2015 .

SIAP - Servicio de Información Agroalimentaria y Pesquera. 2016. Cierre de la producción agrícola para el año 2014. Available at: $<$ http://infosiap.siap.gob.mx/aagricola siap gb/icultivo/index.jsp $>$. Accessed on: July 19, 2016.

Soto-Navarro, S. A.; Williams, G. J.; Bauer, M. L.; Lardy, G. P.; Landblom, D. G. and Caton, J. S. 2004. Effect of field pea replacement level on intake and digestion in beef steers fed byproducts-based medium-concentrate diets. Journal of Animal Science 82:1855-1862.

Stanford, K.; Wallins, G. L.; Lees, B. M. and Mündel, H. H. 1999. Use of lentil screenings in the diets of early weaned lambs and ewes in the second trimester of pregnancy. Animal Feed Science and Techonology 81:249-264.

Surra, J.; Purroy, A.; Muñoz, F. and Treacher, T. 1992. Lentils and faba beans in lamb diets. Small Ruminant Research 7:43-49.

USDA - United States Department Agriculture. 1992. United States standards for grades of slaughter lambs, yearling and sheep. United States Department Agriculture, Monticello, UT, USA.

Van Soest, P. J.; Robertson, J. B. and Lewis, B. A. 1991. Methods for dietary fiber, neutral detergent fiber, and nonstarch polysaccharides in relation to animal nutrition. Journal of Dairy Science 74:3583-3589.

Villalobos, G.; Rodríguez-Almeida, F. A.; Lara-Camargo, G.; Estrada, J. C.; Zapata, M. and Dominguez, D. 2006. Evaluation of animal performance in crossbred hair lambs fed with a high concentrate diets. In: Proceedings of Western Section of the American Society of Animal Science 57:387-388.

Williams, P. E. V.; Pusztai, A. J.; Macdearmid, A. and Innes, G. M. 1984. The use of kidney beans (Phaseolus vulgaris) as protein supplement in diets for young rapidly growing beef steers. Animal Feed Science and Technology 12:1-10. 